\title{
Comparison of Antibody Titre Against Salmonella Species among Healthy Individuals and Febrile Patients
}

\author{
Achut Barakoti, ${ }^{1}$ Junu Richhinbung Rai, ${ }^{1}$ Ram Prasad Adhikari, ${ }^{1}$ Laxmi Kant Khanal ${ }^{1}$ \\ ${ }^{1}$ Department of Microbiology, Nepal Medical College and Teaching Hospital, Kathmandu, Nepal.
}

\begin{abstract}
Background: Widal tube agglutination test is a widely used laboratory test for diagnosis of enteric fever especially in resource limited countries where blood culture are not routinely available. We studied the titres from different groups including febrile and healthy populations in order to identify the significant agglutination titre. Materials and Methods: This was a hospital based cross-sectional study. Subjects were divided into three groups: 1) 60 healthy blood samples from volunteer students, 2) 60 febrile non-typhoidal cases and 3) 58 culture positive patient for enteric fever. Results: Among 60 apparently healthy volunteers, agglutination of $\geq 1: 20$ for anti $\mathrm{O}$ and anti-H titres against serotype Typhi were seen in 40 and 46 samples respectively. A significant proportion of sample had a titre of $\geq 1: 80(n=19)$ and 1:160 $(n=14)$ for anti $O$ and anti-H titres against serotype Typhi respectively among healthy individuals. Similar observations were seen in febrile non typhoidal cases except for one which had a titre of $\geq 1: 320$ for anti $\mathrm{O}$ and anti-H titres against serotype Typhi. In blood culture positive typhoid cases, 56 samples showed agglutinations of $\geq 1: 80$ for both anti $\mathrm{O}$ and anti-H titres against serotype Typhi. However two of the total sample tested showed no agglutinations. In all cases from three groups, anti-H titre for S. enterica serotype Paratyphi A and B were below 1:80. Conclusions: Widal test can be used as presumptive diagnostic tool in all the suspected cases of enteric fever if the titres are specifically raised.
\end{abstract}

Keywords: enteric fever; titre; widal aggultination test.

\section{INTRODUCTION}

Typhoid and Paratyphoid fever are invasive disease which represents the classical clinical syndromes associated with the members of the genus Salmonella that are most closely and constantly linked to human hosts. ${ }^{1}$ The term enteric fever coined to embrace both typhoid and paratyphoid, has been defined by Levine et al in 1983 as 'A generalized infection of the reticuloendothelial system and intestinal lymphoid tissue accompanied by sustained fever and bacteremia". Globally, typhoid is far more common than paratyphoid ${ }^{1}$. Death due to typhoid fever is in between 128000 to 161000 every year. ${ }^{2}$ Total estimated 11-20 million people get sick from typhoid is probably an underestimate because of poor diagnostics facilities in underdeveloped countries. Several options exist for diagnosing enteric fever: clinical signs and symptoms; serological markers; bacterial culture; antigen detection; and DNA amplification. None is entirely satisfactory. The clinical diagnosis of typhoid fever is difficult because the manifestations of the disease are diverse and there are many causes of prolonged fever in typhoid endemic regions. ${ }^{3,4}$

Enteric fever (locally known as Bisham Jwor or Myade Jwor) is endemic in Nepal and constitutes a major cause of morbidity and mortality primarily affecting the children and young adults. The disease occurs sporadically throughout the year with a peak incidence /outbreaks during summer (monsoon) season and is attributed to contamination of foods and drinking water. Fecal contamination of drinking water source / supply system is common in Nepal. ${ }^{5}$ Kathmandu, the capital city of Nepal, has been previously coined an enteric fever capital of the world. The population of Kathmandu is increasing and available figures suggest that enteric fever caused by Salmonella enterica serotype Typhi, Salmonella enterica serotype Parayphi $A$ and Salmonella enterica serotype Paratyphi $B$ show no significant signs of decreasing. Furthermore, recent research demonstrates that the ratio of disease caused by these two organisms is shifting towards S. Paratyphi A. ${ }^{6}$ Isolation of Salmonellae from blood,

Correspondence: Dr. Achut Barakoti, Department of Microbiology, Nepal Medical College and Teaching Hospital, Kathmandu, Nepal. Email: achutpr@hotmail.com. Phone: +977-9841590776. DOI: 10.3126/jcmsn.v14i3.20860. Article received: 2018-06-24. Article accepted: 2018-09-10. 
stool or urine, bone marrow is gold standard for diagnosis of enteric fever. ${ }^{7}$ Although the culture positive rate for Salmonella enterica serotype Typhi, Salmonella enterica serotype Parayphi $A$ and Salmonella enterica serotype Paratyphi $B$ is very less of total blood culture samples collected from feverish patients, it still indicates the major public health importance of this disease in Nepal. ${ }^{8}$ Developed by Georges Fernand Isidore Widal to aid the diagnosis of enteric fever, Widal test is based on demonstration of the presence of agglutinin (antibody) in the serum of an infected patient, against the $\mathrm{H}$ (flagellar) and $\mathrm{O}$ (somatic) antigens of Salmonella enterica serotype Typhi, Salmonella enterica serotype Parayphi $A$ and Salmonella enterica serotype Paratyphi $B$, during the acute and convalescent period of infection. Usually up to $70 \%$ of adults show an early rise of antibody titre in the first week of infection. ${ }^{7}$ Widal agglutination test is a widely used laboratory test for serological diagnosis of enteric fever throughout the world. The term titre here is used to denote the highest dilution of the serum at which antibody activity is demonstrable, which is usually expressed as the reciprocals of the dilution of the serum. ${ }^{9}$

\section{MATERIALS AND METHODS}

This hospital based cross sectional study was done in the Department of Microbiology, NMCTH, Nepal from August 2016 to July 2017. Ethical clearance was obtained after oral presentation of research proposal from institutional research/review committee of Nepal Medical College Teaching Hospital (July 2015). The study population was divided into 3 groups.

\section{Group one}

A total of 58 patients attending the NMCTH over one year of study duration who was diagnosed as typhoid/paratyphoid fever as indicated by the isolation of Salmonella enterica serotype Typhi, Salmonella enterica serotype Parayphi $A$ and Salmonella enterica serotype Paratyphi $B$ from the blood, feaces, urine or bone marrow culture.

\section{Group two}

A total of 60 febrile non-enteric patients (culture negative for Salmonella enterica serotype Typhi, Salmonella enterica serotype Parayphi $A$ and Salmonella enterica serotype Paratyphi B)

\section{Group three}

A total of 60 normal apparently healthy individuals (First year MBBS students).
Detailed work up was done based on complete history and physical examination of the patients and students as per the proforma. Complete history including previous history of enteric fever, previous history of fever treated with antibiotics, any features suggestive of viral infection, past anti -typhoid vaccination history were taken.

$2 \mathrm{ml}$ of blood was drawn and clear serum was separated from it immediately. The serum samples were first processed with slide agglutination method as a primary screening procedure than for all visible agglutination, standard tube dilution method was processed. Four sets of test tubes were taken and labeled from 1 to 7 for $\mathrm{O}, \mathrm{H}, \mathrm{AH}$ and $\mathrm{BH}$ antibody detection.1.9 $\mathrm{ml}$ of isotonic saline was transferred into the tube No.1 with the help of pipette .To each of the remaining tubes $(2$ to 7), $1.0 \mathrm{ml}$ of isotonic saline was added. To the tube numbered as 1 of each row, $0.1 \mathrm{ml}$ of the serum sample to be tested was added and mixed well. $1.0 \mathrm{ml}$ of the diluted serum from tube no. 1 was transferred to tube no. 2 and was mixed well. $1.0 \mathrm{ml}$ of the diluted sample from tube no. 2 was transferred to tube no.3 and will be mixed well. These serial dilutions were continued till tube no. 6 in each set. Than $1.0 \mathrm{ml}$ of the diluted serum from tube No.6 of each set was discarded. Tube No.7 in all the sets, served as a saline control. By this way the dilution of the serum sample achieved in each set was as follows:

\begin{tabular}{|lcccccc|}
\hline Tube No: & 1 & 2 & 3 & 4 & 5 & 6 \\
Dilutions: $1: 20$ & $1: 40$ & $1: 80$ & $1: 160$ & $1: 320$ & $1: 640$
\end{tabular}

Now, to all the tubes (1 to 7) of each set, one drop of the respective Widal test antigen suspension $(\mathrm{O}, \mathrm{H}, \mathrm{AH}$ and $\mathrm{BH})$ from the reagent vials were added and mixed well. The tubes were covered and incubated at 37C overnight (approximately 18 hours) in water bath. Next day, each tube was observed for the agglutination.

The test results will be scored as following: 0 (no agglutination $), 1+(25 \%$ agglutination $), 2+(50 \%$ agglutination), $3+(75 \%$ agglutination $), 4+(100 \%$ agglutination).

According to World Health Organization (WHO), regional office for South East Asia, for the visualization and test to be assumed as positive there should be at least $50 \%$ agglutination. Initial positive screening test will be further diluted for the determination of the strength of antibody by titre. The maximum dilution that exhibits $2+$ or $50 \%$ agglutination is considered as titre of antibody present in that individual. 
RESULTS

A total of 60 blood sample (healthy volunteer students) were tested for widal agglutination titre. An agglutination titre of $\geq 1: 20$ for Salmonella Typhi $\mathrm{O}$ and $\mathrm{H}$ antigen were seen in 40 and 46 samples respectively (Table 1). A significant proportion of sample had a titre of 1:80 for $\mathrm{O}$ antigen (17 sample). Of total, 2 sample had a titre after the blood culture results came positive. All isolates were Salmonella enterica serotype Typhi (S. Typhi). Out of total samples, 56 samples showed agglutination of $\geq 1: 80$ for both $\mathrm{O}$ and $\mathrm{H}$ antigen. A titre of 1:160 for $\mathrm{O}$ and $\mathrm{H}$ antigen were seen in 22 and 32 samples and $\geq 1: 320$ titre were seen in 18 and 20 samples respectively. Remaining 2 showed no agglutinations. None showed widal titre of more than 1:80 for $\mathrm{AH}$ and $\mathrm{BH}$ antigen

\begin{tabular}{|lrrrrrrr|}
\hline Table 1. Agglutination titre from healthy individuals. (Table 3). & & & & \\
\hline Aggultinations & NA & $\mathbf{1 : 2 0}$ & $\mathbf{1 : 4 0}$ & $\mathbf{1 : 8 0}$ & $\mathbf{1 : 1 6 0}$ & $\mathbf{1 : 3 2 0}$ & $\mathbf{1 : 6 2 0}$ \\
S.Typhi O agglutinin & 20 & 11 & 10 & 17 & 1 & 1 & 0 \\
S.Typhi H agglutinin & 14 & 10 & 13 & 9 & 12 & 1 & 1 \\
S.Paratyphi AH agglutinin & 34 & 8 & 11 & 7 & 0 & 0 & 0 \\
S.Paratyphi BH agglutinin & 42 & 11 & 7 & 0 & 0 & 0 & 0 \\
\hline *NA: No Agglutinations & & & & & &
\end{tabular}

Table 2. Aggultination titre from febrile non-typhoidal cases.

\begin{tabular}{|lrrrrrr|}
\hline Aggultinations & NA & $1: 20$ & $1: 40$ & $1: 80$ & $1: 160$ & $1: 320$ \\
S.Typhi O agglutinin & 15 & 10 & 13 & 18 & 4 & 0 \\
S.Typhi H agglutinin & 12 & 11 & 11 & 10 & 15 & 1 \\
S.Paratyphi AH agglutinin & 29 & 13 & 14 & 4 & 0 & 0 \\
S.Paratyphi BH agglutinin & 46 & 9 & 4 & 1 & 0 & 0 \\
\hline
\end{tabular}

*NA: No Agglutinations

\begin{tabular}{|lrrrrrrr|}
\hline Table 3. Aggultination titre from culture proven enteric fever cases. \\
\hline Aggultinations & NA & $\mathbf{1 : 2 0}$ & $\mathbf{1 : 4 0}$ & $\mathbf{1 : 8 0}$ & $\mathbf{1 : 1 6 0}$ & $\mathbf{1 : 3 2 0}$ & $\mathbf{1 : 6 2 0}$ \\
S.Typhi O agglutinin & 2 & 0 & 0 & 16 & 22 & 12 & 6 \\
S.Typhi H agglutinin & 2 & 0 & 0 & 4 & 32 & 14 & 6 \\
S.Paratyphi AH agglutinin & 17 & 19 & 18 & 4 & 0 & 0 & 0 \\
S.Paratyphi BH agglutinin & 24 & 18 & 16 & 0 & 0 & 0 & 0 \\
\hline
\end{tabular}

*NA: No Agglutinations

of $\geq 1: 160$ for $O$ antigen. Similarly, among 46 sample showing titre of $\geq 1: 20$ for Salmonella Typhi $\mathrm{H}$ antigen, 9 had a titre of $1: 80,12$ had a titre of $1: 160,1$ had a titre of $1: 320$ and 1 had a titre of 1:640. On the other hand, 34 had no agglutination for $\mathrm{H}$ antigen for Salmonella Paratyphi A, 8 had $1: 20,11$ had a titre of 1:40 and 7 had of 1:80 titre. Similarly, 42 had no agglutination for $\mathrm{H}$ antigen of Salmonella Paratyphi B, 11 had a titre of 1:20,7had a titre of 1:40 and none had titre of 1:80 (Table 1). Widal agglutination test was also performed for 60 febrile non-typhoidal cases. One case had a titre of 1:320 for for S.Typhi H titre. Four and fifteen cases showed the titration of $1: 160$ for both $\mathrm{O}$ and $\mathrm{H}$ antigen of S.Typhi respectively. For others, the titrations were almost comparable with the normal healthy control groups (Table 2).

A total of 58 blood culture positive cases were sampled for Widal agglutination test immediately

\section{DISCUSSION}

Widal test is second most commonly used test for diagnosis of enteric fever. ${ }^{10}$ Widal test is easy, inexpensive and relatively non invasive. ${ }^{11}$ However, as all serological test, widal test also has its limitations. Local titre may provide the difficulties in interpretation of result. The titre may be variable in patient infected with organisms with crossreacting antigens. ${ }^{12}$ Current reference cutoff value for widal test in Nepal is 1:80 for both $\mathrm{O}$ and $\mathrm{H}$ antigens. ${ }^{7}$ Maxinum number of sample from healthy students showed a titra for $\mathrm{O}$ antigen and $\mathrm{H}$ antigen were in 1:80 diltuions and 1:160 dilutions respectively. Only two sample showed anti-O titre of $\geq 1: 160$ and two showed anti-H titre of $\geq 1: 320$. Similar seropositivity rate were seen in a study done by Punil et al. ${ }^{10}$ Hence, taking cutoff value of 1:80 $\mathrm{O}$ antigen seems to be significent whereas that for $\mathrm{H}$ antigen appears to be significent if revised to $1: 160$. Consedering cut-off value of 1:80 for $\mathrm{O}$ and 1:160 for $\mathrm{H}$ antigen were also significent in Ethiopoa 
which is also another endemic country for enteric fever. ${ }^{13}$ Similar kind of finding were suggested by a sutdy done in Tribhuwan University Teaching Hospital by Pokharel et al. ${ }^{7}$ In contrast, a study conducted in 2000 vietnames patients showed that taking the o-agglutinin titre of 200 or more and $\mathrm{H}$ agglutinin titre of 100 or more, Widal test would diagnosed $74 \%$ of blood culture positive enteric fever cases. ${ }^{12}$ Taking high titre only as a positive finding may relatively increases the specificity but at the same time may miss the enteric fever cases with low titre. In another study done by Raymi et al in Holland, seropositivity was found only in $1 \%$ of the total sample tested. This signifies that the cut -off value seems to be applicable for only endemic area. Current study also showed a low level of salmonella paratyphi $\mathrm{AH}$ and $\mathrm{BH}$ titre in student control group which signifies the low prevelance of these organism causing enteric fever fever in our part. This finding is correnponding the finding of Prajapati et al where they have reported low preveane rate of Salmonella paratyphi compared to Salmonella Typhi in Kathmandu. ${ }^{4}$ In our study, among 60 febrile but culture negative for Enteric fever patients whose serum sample were tested for Widal aggultination test, four of patient had a titre of 1:160 for Salmonella Typhi H and O antigen. This shows that the chance of high titre in non enteric fever should be clearly monitored. Previous vaccination, past infection cross reacting antibody from current infection may also cause the raise level of widal titre which we were unable to exclude in this current study. In cases of culture proven enteric fever cases, most of the cases showed a high titre of $\geq 1: 160$ for both $\mathrm{O}$ and $\mathrm{H}$ antigen. However four of the sample showed a titre of 1:80 for both the $\mathrm{O}$ and $\mathrm{H}$ antigen and 2 gave no aggultination for all four antigens tested. This finding is similar to the finding of other different studies. ${ }^{14,15}$ The low level of aggultination titre might corresponde with the early presentation of patient to OPD whose antibody titre level has increased yet. ${ }^{1}$ There may be a chances of getting high agglutination titre in these caeses giving no agglutinations or low level of agglutination if we had collected the convalescent phase serum.

\section{CONCLUSIONS}

Widal aggultination test results showing high titre 1:160 or more can be consider as presumptive diagnostic tool in all the suspected enteric fever cases where culture facilities are not avaliable.

\section{ACKNOWLEDGEMENTS}

This research was funded by Nepal Medical College Institutional Research Committee.

\section{Conflict of Interest: None}

\section{REFERENCES}

1. Forsyth JRL. Typhoid and Paratyphoid, In: Microbiology and Microbial Infections, Topley and Wilson's $\left(19^{\text {th }}\right.$ ed) 1999:459-71

2. World Health Organization. (2018). Typhoid. [online] Available at: http://www.who.int/ mediacentre/factsheets/typhoid/en

3. Wain J, Hosoglu S. The laboratory diagnosis of enteric fever. J Infect Developing Countries 2008;2(6):421-5. https://doi.org/10.3855/ jidc. 155

4. Prajapati B, Rai GK, Rai SK, Upreti HC, Thapa M, Singh $G$ et al. Prevalence of Salmonella typhi and paratyphi infection in children:a hospital based study. Nepal Med Coll J 2008;10(4):238-41. PMID: 19558061.

5. Pokharel P, Rai SK, Karki G, Katuwal A,Vitrakoti R, Shrestha SK. A study of enteric fever and antibiogram of Salmonella isolates at a teaching hospital in Kathmandu valley. Nepal Med Coll J 2009;11(3):176-8. PMID: 20334064.

6. Karkey A, Aryal A, Basnyat B, Barker S. Kathmandu, Nepal: Still an enteric fever capital of the world. J Infect Dev countries
2008;2(6):461-5. https://doi.org/10.3855/ jidc. 162

7. Pokhrel BM, Karmacharya R, Mishra SK, Koirala J. Distribution of antibody titer against Salmonella enterica among healthy individuals in nepal. Ann Clin Microbiol Antimicrob. 2009 Jan 7;8:1. https:// doi.org/10.1186/1476-0711-8-1

8. Crump JA, Luby SP, Mintz ED. The global burden of typhoid fever. Bull World Health Organ. 2004 May;82 (5):346-53. PMCID: PMC2622843.

9. Chakraborty P, Immune response, In: A test book of Microbiology(2ed ed.), New Central book agency(P)Ltd, India 2003;159-73

10. Punia JN, Joshi RM, Gupta V, Arora RK. Determination of baseline widal titres from Chandigarh. Indian $\mathrm{J}$ Med Microbiol 2003;21:21-144. http://www.ijmm.org/ text.asp?2003/21/2/144/7999

11. Willke A, Ergonul O, Bayar B. Widal test in diagnosis of typhoid fever in Turkey. Clin Diagn Lab Immunol. 2002 Jul;9(4):938-41. 10.1128/CDLI.9.4.938-941.2002

12. Parry CM, Hoa NT, Diep TS, Wain J, Chinh 
Barakoti et al. Health Comparison of Antibody Titre Against Salmonella Species..

NT, Vinh H, Alemayehu H. Value of a singletube widal test in diagnosis of typhoid fever in Vietnam. J Clin Microbiol. 1999 Sep;37 (9):2882-6. PMID: 10449469

13. Andualem G, Abebe T,Kebede N Mihret A, Gebre SS, Mihret A, Alemayehu H.A comparative study of Widal testwith blood culture in the diagnosis of typhoid fever in febrile patients. BMC Research Notes 2014 7:653. 10.1186/1756-0500-7-653.

14. Sherwal BL, Dhamija RK, Randhawa VS Jais
M, Kaintura A, Kumar M. A Comparative Study of Typhidot and Widal Test in Patients of Typhoid Fever JIACM 2004; 5(3): 244-6. Available at: http://medind.nic.in/jac/t04/i3/ jact04i3p244.pdf

15. Hosoglu S, Boşnak V, Akalin S, Geyik MF, Ayaz C. Evaluation of false negativity of the Widal test among culture proven typhoid fever cases. J Infect Dev Ctries. 2008 Dec 1;2 (6):475-8. https://doi.org/10.3855/jidc. 165

Citation: Barakoti A, Rai JR, Adhikari RP, Khanal LK. Comparison of Antibody Titre Against Salmonella Species among Healthy Individuals and Febrile Patients. JCMS Nepal. 2018;14(3):132-6. 